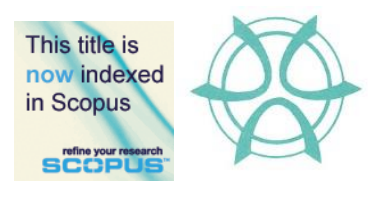

PLANNING MALAYSIA:

Journal of the Malaysian Institute of Planners

VOLUME 16 ISSUE 3 (2018) Page 320 - 331

\title{
IDENTIFICATION OF STRATEGIES FOR URBAN AGRICULTURE DEVELOPMENT: A SWOT ANALYSIS
}

\author{
Pushpawani Ramaloo $^{1}$, Chamhuri Siwar ${ }^{2}$, Choong Yeun Liong ${ }^{3}, \&$ Anizan Isahak ${ }^{4}$ \\ ${ }^{1,2}$ Institute for Environment and Development \\ ${ }^{3}$ School of Mathematical Sciences \\ ${ }^{4}$ School of Environmental Studies and Natural Resource Management \\ UNIVERSITI KEBANGSAAN MALAYSIA
}

\begin{abstract}
Population growth is the major reason for increased food demands and countries face difficult challenges in ensuring food security. This study was conducted to investigate the prospects of urban agriculture (UA) development in Penang state, Malaysia, from the experts' perspective, particularly on the strengths, weaknesses, opportunities and threats (SWOT). Fifty-seven Penang state stakeholders were interviewed. This study applied qualitative analysis method using SWOT analysis to identify and prioritize strategies for urban agricultural development in order to assist planners to manage urban agriculture for achieving food security in urban areas. Based on the results of the SWOT analysis, strategic plans for urban agriculture development system were prioritized into legal framework, financial, infrastructure, land, water, environment and health, social, marketing, and research and development aspects. Finally, a number of strategies for sustainable development of urban agriculture were outlined in order to reduce the weaknesses, avoid the threats, improve the strengths, and grasp the opportunities for the development of urban agriculture production in the Penang state.
\end{abstract}

Keywords: urban agriculture, SWOT analysis, strategic plan, stakeholders, sustainable development 
PLANNING MALAYSIA

Journal of the Malaysia Institute of Planners (2018)

\section{INTRODUCTION}

A variation of urban agriculture systems exists globally, depending on local socio-economic characteristics, populations, geographic, climate and political conditions. Urban agriculture (UA) and peri-urban agriculture (PUA) focuses on the production of food and non-food products. Technical UA implicates different activities for food production such as horticulture, mycoculture, apiculture, aquaculture, floriculture, and cultivation of plants, tree crop and livestock (de Bon, Parrot, \& Moustier, 2010; Gallaher \& Njenga, 2014).

UA has ample potential to yield positive social, economic and environmental returns for cities and their citizens and has been noted and received attention from city planners, policymakers, and scholars (Mougeot, 2005; Colasanti, Hamm, \& Litjens, 2012; Drake \& Lawson, 2015). A survey of UA practices across the globe indicates that factors like urban ecosystems remain connected to urban planning, design, and management for resilience (Scarlett \& Boyd, 2013), urban landscape (Saha \& Eckelman, 2017), land use preferences (Lovell, 2010), water management practices (Cohen \& Reynolds, 2015), innovative forms of green urban architecture practices (Specht et al., 2014), quality of governance (Walker, 2015), legal-technical, policies, bureaucratic rules and procedures (Mendes, 2008), and are highly supportive for sustainable development of UA. A strong policy is needed to feed the entire world population, to guaranteeing the protection and preservation of natural resources for future generations to achieve sustainability. Therefore, implementation of any policy should be supported and shared by the relevant agencies, urban farmers, urban dwellers, community and society, so that maximum impacts and relevance will be achieved.

Urban and peri-urban agriculture (UPA) in Malaysia play an important role as part of the supply chain of cheap food within the country and in managing urban and peri-urban open space (Ramaloo \& Siwar, 2016). This also includes related activities such as production, processing and marketing of products to supplier or for direct sale. The scale of UPA in Malaysia is determined by the land availability and its size, water availability, climate factor, labour, skills, legislative support, and finance.

UPA in Penang state is an activity that covers crop and livestock production and is practiced under different circumstances. UPA in Penang state is practiced by school children, community residents, senior citizens, private and public employees, individuals, and commercial urban farmers. UPA in Penang can contribute to the urban populace in a situation of drastic urban development, high oil prices, and expensive raw commodity prices. The main benefit of urban farming is for the poor to grow their own food on plots in urban areas, thus, increasing access to indispensable food, and they can also sell the surplus beyond their consumption to the urban market. 
Pushpawani Ramaloo, Chamhuri Siwar, Choong-Yeun Liong, \& Anizan Isahak

Identification of Strategies for Urban Agriculture Development: A SWOT Analysis

The aim of this study is to examine in depth the existence of UA development in Penang as well as to assist in the formulation of strategies for UA development for policy makers and planners. This study identifies internal and external factors of urban agriculture development. The SWOT analysis of internal factors can be classified as strengths (S) or weaknesses (W), and external factors can be classified as opportunities $(\mathrm{O})$ or threats $(\mathrm{T})$.

\section{RESEARCH BACKGROUND}

\section{Study Area}

This study was conducted in the Penang state, located on the northwest coast of Peninsular Malaysia, by the Strait of Malacca. It has two separate areas, namely the Penang Island and Seberang Perai (formerly known as Province Wellesley) on the mainland. Penang has five administrative districts, namely the North-East district (Daerah Timur Laut) and South-West district (Daerah Barat Daya) on the Penang Island; and the North Seberang Perai district (Daerah Seberang Perai Utara), Central Seberang Perai district (Daerah Seberang Perai Tengah) and South Seberang Perai district (Daerah Seberang Perai Selatan) in Seberang Perai. Penang has a land area of 1,030 square kilometres (Department of Statistics Malaysia, 2011). Small and larger scale agriculture in Penang state are included in the category of urban and suburban agriculture. The land in Penang is considered among the best farming land suitable for all types of crop production. Penang farmers practice crops production (staples, vegetables, fruit, and herbs), staples and cash-crops production, mixed farming production (crops and livestock), vegetable production, fruit production, plant/flowers production, and herbs plants production (Ramaloo, Siwar, \& Isahak, 2017).

\section{SWOT Analysis}

A SWOT (Strengths - Weaknesses - Opportunities - Threats) analysis is a method used to assist in identifying strategic directions for an organization. In the early 1960s, the Harvard Business School Faculty developed the SWOT organizing framework of matching an organization's internal factors (resources, capabilities, and limitations) with its external environment as a first step in the process of strategy development (Hill \& Westbrook, 1997) and its relation in making decision (Shrestha, Alavapati, \& Kalmbacher, 2004). The SWOT analysis is a strategic planning tool concerned with the analysis of an organization's internal and external environments (Salmi, Ahmed, \& Hasnan, 2015; David, David, \& David, 2016). This analysis compares strengths and weaknesses (the resources) of an organization to opportunities involved in the growth and improvement of an organization and examines the external threats generated by its environment (Valentin, 2005; Ommani, 2011). SWOT analysis is typically carried out in the form of a group meeting with common themes or interactions (Brooks, Heffner, 
PLANNING MALAYSIA

Journal of the Malaysia Institute of Planners (2018)

\& Henderson, 2014), although it is not impossible for the SWOT analysis of a particular subject to be identified by a single individual. According to McNutt (1991), a group of people represents different perspectives on the action to be done and different expertise in order to identify the SWOT based issues. The meeting with a group may be either prepared with relevant documents or questionnaires. Weihrich (1999) modified the SWOT into the format of a matrix, matching the internal factors (strengths and weaknesses) with its external factors (opportunities and threats) to generate strategies. As a framework, SWOT can be represented in a simple two-by-two matrix, as shown in Figure 1. This matrix representation allows key issues to be summarized and then debated within a participatory strategy-making session to best surface the ideas and specialized knowledge of key parties within the stakeholders or organization.

\begin{tabular}{|l|c|c|}
\hline & Positive (to achieve the goal) & Negative (to achieve the goal) \\
\hline Internal origin & Strengths & Weaknesses \\
\hline External origin & Opportunities & Threats \\
\hline
\end{tabular}

Figure 1: SWOT Analysis matrix

SWOT analysis matrix is one of the efficient qualitative models that have been widely used for various subjects. Although SWOT analysis has been generally used in business plans, nowadays it is used to evaluate issues and policies related to decision-making and also to evaluate sustainable agriculture in a systematic way. Falsolayman and Sadeghi (2013) used SWOT analysis to evaluate sustainable agriculture in a systematic way even though SWOT analysis has been generally used in business plans. SWOT analysis has also been used for sustainable development (Ommani, 2011; Reihanian, Mahmood, Kahrom, \& Tan, 2012; Zhang, 2012; Ghorbani, Valiollah, Rafiaani. \& Azadi, 2015). While, Halla (2007), Liu (2013), and Valipour, Akbari and Zaker (2013) used SWOT analysis to formulate strategies for UA development.

This study uses SWOT analysis tool as a strategic planning approach to indicate strategies for developing UA in the Penang state, Malaysia. This method has been adapted to identify critical factors affecting the development of UA and to undertake preliminary decision making and planning (Arslan \& Er, 2008) for developing UA in mega cities. SWOT analysis is a continuation of the situation analysis of internal-external factors, where 'strengths' apply to current forces associated with a UA whereas 'opportunities' refer to what actions could be taken to enhance this development, and 'weaknesses' refer to current problems whereas 'threats' are problems waiting to happen. The combination of these interactions produced some general strategies to develop urban agricultural activities to achieve food security and sustainability in Penang state. 
Pushpawani Ramaloo, Chamhuri Siwar, Choong-Yeun Liong, \& Anizan Isahak

Identification of Strategies for Urban Agriculture Development: A SWOT Analysis

\section{Data Preparation and Analysis}

This research is a qualitative study. To conduct the SWOT analysis, face to face semi-structured interviews with different stakeholder groups were carried out. Expert interviews were considered as an efficient method of gathering data, especially in exploratory phase of a project (Bogner, Littig, \& Menz, 2009). An expert group workshop and personal interviews were held amongst 57 member participants of urban farmers, agriculture stakeholders, municipal city stakeholders and university academic members (Table 1).

Table 1: Basic data of the participants

\begin{tabular}{clc}
\hline Number & \multicolumn{1}{c}{ Type of Participant } & Number of Participants \\
\hline 1 & Urban Farmers & 40 \\
2 & Agriculture Stakeholders & 12 \\
3 & Municipal City Stakeholders & 2 \\
4 & University Academic Members & 3 \\
\hline
\end{tabular}

In order to explore different aspects of the experts' views, experiences and perspectives on developing UA, the interview questionnaire mainly consists of open-ended questions. Interview sessions were held in each district of the Penang state and covered topics and questions related to UA policies, research, marketing, opportunities, challenges and future prospects. The SWOT analysis does not require any special tool to make the questionnaire or calculate the data collected from the stakeholders. The most important part of this analysis were open interviews and focus groups to find the strengths, weaknesses, opportunities and threats, and finally develop a strategic plan for UA development.

\section{RESULTS}

Based on the observations and data from Penang stakeholders, the SWOT factors were mapped one by one. Table 2 shows the list of strengths, weaknesses, opportunities, and threats in the SWOT analysis of Penang stakeholders. The authors outlined SWOT matrix that was based on the identification and categorization of major UA issues within each cell of the matrix.

A lot of interesting facts about UA issues were found, which can be classified in each of the SWOT components. SWOT analysis itself actually includes two factors: internal factors (strengths and weaknesses) and external factors (opportunities and threats). Internal factors are factors which influence is wholly derived from the study object, in this case urban agriculture development in Penang state itself can bring a positive influence (strength) and can also bring a negative influence (weakness). Meanwhile, external factors are factors that originate outside of development of the UA but from nature, the environment, and the influence of other outsiders. The SWOT analysis has been useful in deciding the concept strategy accurately. 
Table 2: SWOT analysis of Urban Agriculture (UA) in Penang State

\begin{tabular}{|c|c|}
\hline STRENGTHS & WEAKNESSES \\
\hline $\begin{array}{l}\left(\mathrm{S}_{1}\right) \text { National recognition of UA } \\
\left(\mathrm{S}_{2}\right) \text { Stakeholders support \& encourage the } \\
\text { implementation of UA program } \\
\left(\mathrm{S}_{3}\right) \text { The UA program involves } \\
\text { communities, individuals, schools and } \\
\text { institutions } \\
\left(\mathrm{S}_{4}\right) \text { Farmers initiate networking and } \\
\text { knowledge sharing and experience } \\
\left(\mathrm{S}_{5}\right) \text { Stakeholders provide services, advice } \\
\& \text { technical support to farmers } \\
\left(\mathrm{S}_{6}\right) \text { Stakeholders monitoring the urban } \\
\text { agricultural activities } \\
\left(\mathrm{S}_{7}\right) \text { Increased number of UA gardens } \\
\left(\mathrm{S}_{8}\right) \text { Stakeholders relationship with } \\
\text { farmers on UA development }\end{array}$ & $\begin{array}{l}\left(\mathrm{W}_{1}\right) \text { UA activities are not registered } \\
\left(\mathrm{W}_{2}\right) \text { There is no official plan policy } \\
\text { statements, district plan policy } \\
\text { statements, by-laws, provincial } \\
\text { legislation or policy and federal } \\
\text { legislation for UA } \\
\left(\mathrm{W}_{3}\right) \text { Lack of acknowledgement of urban } \\
\text { agriculture in planning policy } \\
\left(\mathrm{W}_{4}\right) \text { UA is not recognized as a category } \\
\text { of land use that is different from other } \\
\text { land use in urban planning policy } \\
\left(\mathrm{W}_{5}\right) \text { UA whether positive or negative is } \\
\text { not in the official document of the city } \\
\left(\mathrm{W}_{6}\right) \text { Limited of capital for UA } \\
\left(\mathrm{W}_{7}\right) \text { No policies of loans and grants for } \\
\mathrm{UA} \\
\left(\mathrm{W}_{8}\right) \text { Lack of secure tenure on land } \\
\left(\mathrm{W}_{9}\right) \text { Lack of research and extension } \\
\text { systems for UA }\end{array}$ \\
\hline OPPORTUNITIES & THREATS \\
\hline $\begin{array}{l}\left(\mathrm{O}_{1}\right) \text { UA can alleviate poverty and source } \\
\text { of food security for urban poor } \\
\left(\mathrm{O}_{2}\right) \text { UA can provide employment } \\
\text { opportunities } \\
\left(\mathrm{O}_{3}\right) \text { UA can generate income } \\
\left(\mathrm{O}_{4}\right) \text { UA can reduce transportation cost } \\
\left(\mathrm{O}_{5}\right) \text { Experience and lesson of domestic } \\
\text { and global UA development are available } \\
\left(\mathrm{O}_{6}\right) \text { Development of urban agricultural } \\
\text { technologies (seeds, fertilizers, tools and } \\
\text { agricultural machinery) } \\
\left(\mathrm{O}_{7}\right) \text { UA contributes to sustainable } \\
\text { development of agriculture: biodiversity, } \\
\text { environmental protection \& improving } \\
\text { soil fertilization }\end{array}$ & $\begin{array}{l}\left(\mathrm{T}_{1}\right) \text { Use of agricultural land for housing, } \\
\text { industrial and urban development } \\
\left(\mathrm{T}_{2}\right) \text { UA has land issues for access and } \\
\text { availability } \\
\left(\mathrm{T}_{3}\right) \text { Imperfect infrastructure } \\
\left(\mathrm{T}_{4}\right) \text { Domestic food production does not } \\
\text { guarantee food security and availability } \\
\left(\mathrm{T}_{5}\right) \text { Youth not interested in UA activities }\end{array}$ \\
\hline
\end{tabular}

\section{SWOT Strategies}

The UA strategic planning in Penang state marks the beginning towards action and implementation of UA. The success of UA depends on how the key players, namely Ministry of Agriculture and Agro-Based Industry, state government, local government, Food Policy Council, Economic Planning Unit, municipal and city councils, Department of Agriculture, Department of Irrigation and Drainage, Department of Environmental Protection, Health Department, Federal 
Pushpawani Ramaloo, Chamhuri Siwar, Choong-Yeun Liong, \& Anizan Isahak Identification of Strategies for Urban Agriculture Development: A SWOT Analysis

Agricultural Marketing Authority (FAMA), Non-governmental organizations (NGOs), universities and farmers' associations manage and implement urban agricultural activities as a new sector. Based on the SWOT matrix analysis, the authors propose a strategy plan for enabling legal framework, research, and capacity building for relevant stakeholders to develop urban agriculture in Penang to achieve a sustainable urbanization system (Table 3).

Table 3: Proposed Penang urban agriculture strategic plan

\begin{tabular}{|c|c|c|c|c|}
\hline Issue & Goal & Objectives & Strategies & Relevant Authority \\
\hline \multirow[t]{2}{*}{$\begin{array}{c}\text { Legal } \\
\text { Framework }\end{array}$} & \multirow[t]{2}{*}{$\begin{array}{l}\text { Provision of } \\
\text { legal } \\
\text { framework } \\
\text { for UA }\end{array}$} & \multirow[t]{2}{*}{$\begin{array}{l}\text { 1. Develop UA policy } \\
\text { documents } \\
\text { 2. Develop UA law for } \\
\text { territories, states \& } \\
\text { districts (by-laws) } \\
\text { 3. Institutionalize UA } \\
\text { into the structure of the } \\
\text { Municipal Council }\end{array}$} & $\begin{array}{l}\text { 1.Draft UA policy } \\
\text { document } \\
\text { 2. By-law in favour } \\
\text { of UA \& in place of } \\
\text { execution }\end{array}$ & $\begin{array}{l}\text { 1. Ministry of } \\
\text { Agriculture \& Agro- } \\
\text { Based Industry } \\
\text { 2. Food Policy } \\
\text { Council } \\
\text { 3. Economic } \\
\text { Planning Unit }\end{array}$ \\
\hline & & & $\begin{array}{l}\text { 3.Provide UA office } \\
\text { and make sure it } \\
\text { delivers }\end{array}$ & $\begin{array}{l}\text { 1. Municipal and } \\
\text { City Councils }\end{array}$ \\
\hline \multirow[t]{2}{*}{ Financial } & \multirow[t]{2}{*}{$\begin{array}{l}\text { Provision of } \\
\text { financial } \\
\text { allocation for } \\
\text { UA }\end{array}$} & \multirow{2}{*}{$\begin{array}{l}\text { 1. Allocating budget for } \\
\text { UA activity } \\
\text { 2. Identifying loan } \\
\text { facilities for farmers / } \\
\text { households for UA } \\
\text { activities } \\
\text { 3. Identify \& promote } \\
\text { donor funding for UA } \\
\text { activities }\end{array}$} & $\begin{array}{l}\text { 1.Make an estimate } \\
\text { of spending expenses } \\
\text { for UA activity } \\
\text { execution } \\
\text { (commercial, } \\
\text { medium, small and } \\
\text { subsistence for UA) }\end{array}$ & $\begin{array}{l}\text { 1. State government } \\
\text { 2. Local government }\end{array}$ \\
\hline & & & $\begin{array}{l}\text { 2.Create } \\
\text { advertisement } \\
\text { campaign to sponsor } \\
\text { UA activity } \\
\text { 3.Advertise basic } \\
\text { documents to } \\
\text { potential donors of } \\
\text { UA activities }\end{array}$ & $\begin{array}{l}\text { 1. Municipal and } \\
\text { City Councils } \\
\text { 2. Non- } \\
\text { governmental } \\
\text { organizations } \\
\text { (NGOs) }\end{array}$ \\
\hline Infrastructure & $\begin{array}{l}\text { Provision of } \\
\text { UA } \\
\text { infrastructure }\end{array}$ & $\begin{array}{l}\text { 1. Identify UA } \\
\text { technique/ technology } \\
\text { 2. Provide logistical } \\
\text { equipment }\end{array}$ & $\begin{array}{l}\text { 1.Train farmer / } \\
\text { household on } \\
\text { appropriate } \\
\text { technology / } \\
\text { technique for UA } \\
\text { 2.Provide } \\
\text { transportation \& } \\
\text { agricultural } \\
\text { equipment }\end{array}$ & $\begin{array}{l}\text { 1. Municipal and } \\
\text { City Councils } \\
\text { 2. Department of } \\
\text { Agriculture }\end{array}$ \\
\hline \multirow[t]{2}{*}{ Land } & \multirow[t]{2}{*}{$\begin{array}{l}\text { Provision of } \\
\text { land for UA }\end{array}$} & \multirow[t]{2}{*}{$\begin{array}{l}\text { 1.Provide land for UA } \\
\text { activities } \\
\text { 2. Provide security of } \\
\text { tenure for UA }\end{array}$} & $\begin{array}{l}\text { 1.Identify land \& } \\
\text { verified the owner } \\
\text { 2.Make a lease } \\
\text { agreement }\end{array}$ & $\begin{array}{l}\text { 1. Municipal and } \\
\text { City Councils }\end{array}$ \\
\hline & & & $\begin{array}{l}\text { 3.Provide plan, } \\
\text { measurement \& } \\
\text { marking to plant in } \\
\text { the city }\end{array}$ & $\begin{array}{l}\text { 1. Department of } \\
\text { Agriculture }\end{array}$ \\
\hline Water & & & $\begin{array}{l}\text { 1.Identify water } \\
\text { sources }\end{array}$ & $\begin{array}{l}\text { 1. Municipal and } \\
\text { City Councils }\end{array}$ \\
\hline
\end{tabular}


PLANNING MALAYSIA

Journal of the Malaysia Institute of Planners (2018)

\begin{tabular}{|c|c|c|c|c|}
\hline & $\begin{array}{l}\text { Provision of } \\
\text { water for } \\
\text { UA }\end{array}$ & $\begin{array}{l}\text { 1. Ensure clean \& } \\
\text { adequate water supply } \\
\text { for UA activities }\end{array}$ & $\begin{array}{l}\text { 2.Develop } \\
\text { infrastructure for tap } \\
\text { water and } \\
\text { recycling water for } \\
\text { UA irrigation } \\
\text { purposes }\end{array}$ & $\begin{array}{l}\text { 2. Department of } \\
\text { Irrigation and } \\
\text { Drainage } \\
\text { 3. Department of } \\
\text { Environmental } \\
\text { Protection }\end{array}$ \\
\hline & & & $\begin{array}{l}\text { 3.Rainwater } \\
\text { harvesting }\end{array}$ & $\begin{array}{l}\text { 1. Municipal and } \\
\text { City Councils } \\
\text { 2. Farmers' } \\
\text { Association }\end{array}$ \\
\hline \multirow[t]{4}{*}{$\begin{array}{l}\text { Environment } \\
\text { \& Health }\end{array}$} & \multirow[t]{4}{*}{$\begin{array}{l}\text { Promote } \\
\text { environment } \\
\text { and health } \\
\text { aspects of all } \\
\text { UA } \\
\text { development } \\
\text { projects }\end{array}$} & \multirow{4}{*}{$\begin{array}{l}\text { 1. Ensure access to } \\
\text { fresh / nutritious food / } \\
\text { herbs for every } \\
\text { household } \\
\text { 2. Minimize the spread } \\
\text { of diseases in the UA } \\
\text { practice community } \\
\text { 3. Promoting } \\
\text { environmentally- } \\
\text { friendly urban farming } \\
\text { practices } \\
\text { 4. Ensure the } \\
\text { production of nutritious } \\
\text { foods and herbs that } \\
\text { enhance the body's } \\
\text { health system }\end{array}$} & $\begin{array}{l}\text { 1.Providing } \\
\text { assistance to } \\
\text { communities to } \\
\text { diversity gardens } \\
\text { (such as herbs, } \\
\text { vegetables, etc) } \\
\end{array}$ & $\begin{array}{l}\text { 1. Municipal and } \\
\text { City Councils } \\
\text { 2. Department of } \\
\text { Agriculture }\end{array}$ \\
\hline & & & $\begin{array}{l}\text { 2.Build proper } \\
\text { sanitation facilities in } \\
\text { UA activities }\end{array}$ & $\begin{array}{l}\text { 1. Municipal and } \\
\text { City Councils }\end{array}$ \\
\hline & & & $\begin{array}{l}\text { 3.Promoting organic } \\
\text { farming methods and } \\
\text { methods } \\
\text { 4. Promote the use of } \\
\text { organic or natural } \\
\text { foods that are not } \\
\text { processed }\end{array}$ & $\begin{array}{l}\text { 1. Department of } \\
\text { Agriculture } \\
\text { 2. Health } \\
\text { Department }\end{array}$ \\
\hline & & & $\begin{array}{l}\text { 5.Ensure that farmers } \\
\text { / urban households } \\
\text { avoid environmental } \\
\text { pollution } \\
\text { 6.Educate farmers / } \\
\text { urban households on } \\
\text { natural resource } \\
\text { cycle methods }\end{array}$ & $\begin{array}{l}\text { 1. Department of } \\
\text { Agriculture } \\
\text { 2. Department of } \\
\text { Environmental } \\
\text { Protection } \\
\text { 3. Farmers' } \\
\text { Association }\end{array}$ \\
\hline \multirow[t]{2}{*}{ Social } & \multirow{2}{*}{$\begin{array}{l}\text { Achieve } \\
\text { food safety } \\
\text { assurance, } \\
\text { improve } \\
\text { food } \\
\text { nutrition and } \\
\text { promote } \\
\text { sustainable } \\
\text { UA for } \\
\text { households }\end{array}$} & \multirow{2}{*}{$\begin{array}{l}\text { 1. Provide fair } \\
\text { opportunities for UA } \\
\text { activities among social } \\
\text { groups in terms of } \\
\text { gender and social status } \\
\text { 2. Create job } \\
\text { opportunities } \\
\text { 3. Generate income } \\
\text { 4. Reducing household } \\
\text { expenses }\end{array}$} & $\begin{array}{l}\text { 1. Providing land for } \\
\text { UA activity for poor } \\
\text { urban households to } \\
\text { plant and market UA } \\
\text { products }\end{array}$ & $\begin{array}{l}\text { 1. Municipal and } \\
\text { City Councils }\end{array}$ \\
\hline & & & $\begin{array}{l}\text { 2. Ensure UA's } \\
\text { activities as } \\
\text { employment for poor } \\
\text { urban households, } \\
\text { disadvantaged groups } \\
\text { and elderly } \\
\text { 3. Ensure that } \\
\text { farmers / households } \\
\text { / disadvantaged } \\
\text { groups / elderly } \\
\text { generate income and } \\
\text { ensure food safety } \\
\text { through UA activities }\end{array}$ & $\begin{array}{l}\text { 2.Department of } \\
\text { Agriculture } \\
\text { 3. Farmers' } \\
\text { Association }\end{array}$ \\
\hline Marketing & $\begin{array}{l}\text { Marketing of } \\
\text { UA } \\
\text { production }\end{array}$ & $\begin{array}{l}\text { 1. Identify markets for } \\
\text { UA farmers } \\
\text { 2. Promote } \\
\text { diversification of UA } \\
\text { production }\end{array}$ & $\begin{array}{l}\text { 1. Advertise UA } \\
\text { production } \\
\text { 2. Promoting urban } \\
\text { farmer businesses }\end{array}$ & $\begin{array}{l}\text { 1. Municipal and } \\
\text { City Councils } \\
\text { 2. Department of } \\
\text { Agriculture }\end{array}$ \\
\hline
\end{tabular}


Pushpawani Ramaloo, Chamhuri Siwar, Choong-Yeun Liong, \& Anizan Isahak Identification of Strategies for Urban Agriculture Development: A SWOT Analysis

\begin{tabular}{|c|c|c|c|c|}
\hline & & & $\begin{array}{l}\text { 3. Train farmers on } \\
\text { production and } \\
\text { marketing of suitable } \\
\text { UA commodities }\end{array}$ & $\begin{array}{l}\text { 3. Federal } \\
\text { Agricultural } \\
\text { Marketing Authority } \\
\text { (FAMA) } \\
\text { 4. Farmers' } \\
\text { Association }\end{array}$ \\
\hline $\begin{array}{c}\text { Research \& } \\
\text { Development }\end{array}$ & $\begin{array}{l}\text { Research- } \\
\text { based } \\
\text { capacity } \\
\text { building for } \\
\text { UA }\end{array}$ & $\begin{array}{l}\text { 1. Using research-based } \\
\text { on UA issues, } \\
\text { challenges and future } \\
\text { prospect } \\
\text { 2. Conduct research on } \\
\text { identified UA issues } \\
\text { 3. Ensure UA farmers } \\
\text { have UA knowledge } \\
\text { and skills } \\
\text { 4. Conduct research on } \\
\text { identified of UA } \\
\text { technique }\end{array}$ & $\begin{array}{l}\text { 1. Collect, compile } \\
\text { and share } \\
\text { information about } \\
\text { UA } \\
\text { 2. Conduct research } \\
\text { on modern } \\
\text { agricultural } \\
\text { techniques } \\
\text { 3. Conduct UA } \\
\text { workshops / training } \\
\text { / seminars / forums } \\
\text { with various } \\
\text { stakeholders } \\
\text { 4. Keep data record } \\
\text { on UA activities }\end{array}$ & $\begin{array}{l}\text { 1. Municipal and } \\
\text { City Councils } \\
\text { 2. Department of } \\
\text { Agriculture } \\
\text { 3. Department of } \\
\text { Environmental } \\
\text { Protection } \\
\text { 4. Department of } \\
\text { Irrigation and } \\
\text { Drainage } \\
\text { 5. Non- } \\
\text { governmental } \\
\text { organizations } \\
\text { (NGOs) } \\
\text { 6. } \\
\text { University/Research } \\
\text { Institution } \\
\text { 7. Farmers' } \\
\text { Association }\end{array}$ \\
\hline
\end{tabular}

UA will ensure food security and poverty eradication if the authorities can create a clear legal framework. The involvement of various stakeholders in UA should be implemented at all levels through a systematic structure. Capacity building for municipalities should be implemented to ensure that urban agricultural policy objectives are met. UA policy needs to be set up and coordinated by local governments especially in municipalities.

\section{DISCUSSION}

The aim of this study is to understand the involvement, influences, interactions and relationships networking among key stakeholders on developing UA activities and food systems in the study area. The development of UA in Malaysia is still in early stages. Stakeholders and farmers have different perceptions and priorities about the UA. Among the fifty-seven priority stakeholders: Fifty-two of them (Penang Department of Agricultural and urban farmers) were those who have leadership in implementing and involving on UA activities and program; three of them (university academics) were those involved in research and investigation of UA development, while two stakeholders did not have any involvement in implementing UA program (municipal and city council stakeholders).

This research is based on the internal and external (SWOT analysis) factors and strategic planning tool to develop UA. From the analysis, 8 strength factors and 7 opportunity factors as advantages, and 9 weakness factors and 5 threat factors as constraints were identified as facing Penang state UA 
development. From the results of SWOT analysis, strategic plans for UA development system was proposed to include legal framework, financial, infrastructure, land, water, environment and health, social, marketing, and research and development.

\section{CONCLUSION}

UA is an important component of sustainable development. Our findings support local planning practitioners in filling regulatory gaps, and practices of urban agriculture, and in seeking to promote UA in order to achieve food security in urban areas in the near future. These require a system that makes use of stakeholders' integrated role in order to implement the UA strategic plan for Malaysia. In the planning and implementation of integrated UA systems the policymakers and planners plays a key role in the recognition of benefits and other elements that contribute towards the sustainability of the UA system.

\section{ACKNOWLEDGEMENT}

The authors are grateful to Universiti Kebangsaan Malaysia for providing funding under the Arus Perdana (AP 2014-017) and Geran Universiti Penyelidikan (GUP-2017-043) in support of this research project.

\section{REFERENCES}

Arslan, O., \& Er, I. D. (2008). SWOT analysis for safer carriage of bulk liquid chemicals in tankers. Journal of Hazardous Materials, 154, 901-913.

Bogner, A., Littig, B., \& Menz, W. (2009). Introduction: Expert interviews - An introduction to a new methodological debate. In A. Bogner, B. Littig, and W. Menz, (Eds.), Interviewing experts (pp. 1-13). Basingstoke: Palgrave Macmillan.

Brooks, G., Heffner, A. \& Henderson, D. (2014). A SWOT analysis of competitive knowledge from social media for a small start-up business. Review of Business Information Systems, 18(1), 23-34.

Cohen, N., \& Reynolds, K. (2015). Resource needs for a socially just and sustainable urban agriculture system: Lessons from New York City. Renewable Agriculture and Food Systems, 30(1), 103-114.

Colasanti, K. J. A., Hamm, M. W., \& Litjens, C. M. (2012). The city as an 'agricultural powerhouse'? Perspectives on expanding urban agriculture from Detroit, Michigan. Urban Geography, 33(3), 348-369.

David, M. E., David, F. R., \& David, F. R. (2016). The quantitative strategic planning matrix (QSPM): A new marketing tool. Journal of Strategic Marketing, 1-11.

De Bon, H., Parrot, L., \& Moustier, P. (2010). Sustainable urban agriculture in developing countries: A review. Agronomy for sustainable development, 30(1), 21-32.

Department of Statistics Malaysia (2011). Pulau Pinang @ a Glance. Available at https://www.statistics.gov.my/. 
Pushpawani Ramaloo, Chamhuri Siwar, Choong-Yeun Liong, \& Anizan Isahak

Identification of Strategies for Urban Agriculture Development: A SWOT Analysis

Drake, L., \& Lawson, L. (2015). Results of a US and Canada community garden survey: Shared challenges in garden management amid diverse geographical and organizational contexts. Agriculture Human Values, 32(2), 241-254.

Falsolayman, M., \& Sadeghi, H. (2013). An analysis on capabilities of agricultural sector of Southern Khorasan to have a sustainable development managed by the application SWOT model. Iranian Journal Geography and Development, 11(30), 139-156.

Gallaher, C., \& Njenga, M. (2014). Urban agriculture. In P. Thompson, D. Kaplan (Eds.), Encyclopedia of food and agricultural ethics (pp. 1775-82). Dordrecht: Springer Netherlands.

Ghorbani, A., Valiollah, R., Rafiaani. P., \& Azadi, H. (2015). Ecotourism sustainable development strategies using SWOT and QSPM model: A case study of Kaji Namakzar Wetland, South Khorasan province, Iran. Tourism Management Perspectives, 16, 290-297.

Halla, F. (2007). A SWOT analysis of strategic urban development planning: The case of Dar es Salaam city in Tanzania. Habitat International, 31(1), 130-142.

Hill, T. \& Westbrook, R. (1997). SWOT analysis: It's time for a product recall. Long Range Planning, 30(1), 46-52.

Liu, Q. (2013). Development of urban agriculture in Xixian new area. Asian Agricultural Research, 5(8), 23-27.

Lovell, S. T. (2010). Multifunctional urban agriculture for sustainable land use planning in the United States. Sustainability, 2(8), 2499-2522.

McNutt, K. (1991). SWOT before you start. Nutrition Today, 26(1), 48-51.

Mendes, W. (2008). Implementing social and environmental policies in cities: The case of food policy in Vancouver, Canada. International Journal of Urban and Regional Research, 32(4), 942-967.

Mougeot, L. (2005). Agropolis: The social, political, and environmental dimensions of urban agriculture. Earthscan: London.

Ommani, A. R. (2011). Strengths, weaknesses, opportunities and threats (SWOT) analysis for farming system businesses management. African Journal of Business Management, 5(22), 9448-9454.

Ramaloo, P., Siwar, C. \& Isahak, A. (2017). Typologies and constraints of urban agriculture development in Penang, Malaysia. In N. Tiraieyari, A. A. Samah, \& G. N. Mclean (Eds.), Urban farming in Malaysia: Improving food security while greening the environment. Serdang: Universiti Putra Malaysia Publication.

Ramaloo, P. \& Siwar, C. (2016). Status of urban and peri urban agriculture in Malaysia: Implications for developing countries. Proceedings Asia Institute of Technology (AIT): Urban and Peri-Urban Agriculture in Asia. Bangkok, Thailand.

Reihanian, A., Mahmood, N. Z., Kahrom, E., \& Tan, W. H. (2012). Sustainable tourism development strategy by SWOT analysis: Boujagh National Park, Iran. Tourism Management Perspectives, 4, 223-228.

Saha, M., \& Eckelman, M. J. (2017). Growing fresh fruits and vegetables in an urban land-scape: a geospatial assessment of ground level and rooftop urban agriculture potential in Boston, USA. Landscape and Urban Planning, 165, 130141. 
PLANNING MALAYSIA

Journal of the Malaysia Institute of Planners (2018)

Salmi, A., Ahmed, M. N. \& Hasnan, N. (2015). SWOT and TOWS matrix e-government analysis review on Sultanate of Oman. International Journal of Learning and Development, 5(4), 13-23.

Scarlett, L., \& Boyd, J. (2013). Ecosystem services and resource management: institutional issues, challenges, and opportunities in the public sector. Ecological Economics, 115, 3-10.

Shrestha, R. K., Alavapati, J. R. R. \& Kalmbacher, R. S. (2004). Exploring the potential for silvopasture adoption in south-central Florida: An application of SWOTAHP method. Agricultural Systems, 81(3), 185-199.

Specht, K., Siebert, R., Hartmann, I., Freisinger, U. B., Sawicka, M., Werner, A.,...\& Dierich, A. (2014). Urban agriculture of the future: An overview of sustainability aspects of food production in and on buildings. Agriculture and Human Values, 31, 33-51.

Valentin, E. K. (2005). Away with SWOT analysis: Use defensive/offensive evaluation instead. The Journal of Applied Business Research, 21(2), 91-105.

Valipour, S., Akbari, M. R., \& Zaker, H. K. (2013). Strategic planning for urban agriculture development by SWOT (Case Study: Dogonbadan city of Gachsaran). Urban Management, 5(15), 45-57.

Walker, S. (2015). Urban agriculture and the sustainability fix in Vancouver and Detroit. Urban Geography, 37(2), 163-182.

Weihrich, H. (1999). Analyzing the competitive advantages and disadvantages of Germany with the TOWS Matrix - An alternative to Porter's Model. European Business Review, 99(1), 9-22.

Zhang, X. (2012). Research on the development strategies of rural tourism in Suzhou based on SWOT analysis. Energy Procedia, 16, 1295-1299. 